\title{
エコチル調査＼cjkstart熊本大学サブユニットセンターの参加者の特性 一非妊娠時体格及び妊娠期間の体重増加量と周産期予後との関連一
}

\author{
甲斐村美智子 $* 1$, 小田 政子 $* 1$, 三㴊＼cjkstart浩 $* 1,2$, 大場 隆 ${ }^{* 1,3}$, 加藤 貴彦 $* 1,4$ \\ *1 エコチル調査熊本大学サブユニットセンター \\ *2 熊本大学医学部附属病院新生児学講座 \\ $*^{3}$ 熊本大学大学院生命科学研究部産科婦人科学分野 \\ *4 熊本大学大学院生命科学研究部公衆衛生学分野
}

\section{Participant Characteristics in the Kumamoto University Regional Center of Japan Environment and Children's Study (JECS): Association of Pregnancy Outcomes with Pregestational Maternal Body Mass Index and Maternal Weight Gain during Pregnancy}

\author{
Michiko KAIMURA*1, Masako ODA*1, Hiroshi MITSUBUCHI*1,2, \\ Takashi $\mathrm{OHBA}^{* 1,3}$ and Takahiko KATOH*1,4 \\ ${ }^{*}$ IKumamoto University Regional Center, The Japan Environment and Children's Study (JECS) \\ ${ }^{*}$ Department of Neonatology, Kumamoto University Hospital \\ ${ }^{*}$ Department of Obstetrics and Gynecology, Faculty of Life Sciences, Kumamoto University \\ ${ }^{*}$ Department of Public Health, Faculty of Life Sciences, Kumamoto University
}

\begin{abstract}
Purpose: The purpose of this study was to identify participant characteristics in the Kumamoto University Regional Center of the Japan Environment and Children's Study (K-JECS) and to investigate the association of pregnancy outcomes with pregestational maternal body mass index (BMI) and maternal weight gain during pregnancy (MWG).

Methods: The subjects were women with singleton birth, who had been recruited by the K-JECS, and were registered in the data systems for the first and second questionnaires and transcripts of medical records. The subjects were categorized by BMI with further classification by MWG. The chi-squared test and one-way analysis of variance were performed to determine the correlations of BMI and MWG with perinatal outcomes. Logistic regression analysis was performed to examine perinatal outcome risks.

Results: The subject characteristics were similar to the trends observed in the Japanese general population. The odds ratio for natural delivery was low in the overweight groups $(\mathrm{OW})$ and normal weight groups (NW) with excessive weight gain. On the other hand, the risk of cesarean section was high in the $O W$, and risk of induced or accelerated delivery was high in the NW with excessive weight gain. The risks of preterm birth and LBW were high in the insufficient weight gain groups regardless of BMI. The risks of pregnancy-induced hypertension and gestational diabetes were high in the $\mathrm{OW}$.
\end{abstract}

Key words: Japan Environment and Children’s Study（エコチル調査）, pregestational maternal body mass index (非妊娠時体格), maternal weight gain during pregnancy (妊娠期間の体重増加量), pregnancy outcomes（周産期予後）

受付 2017 年 1 月 17 日, 受理 2017 年 3 月 13 日

Reprint requests to: Michiko KAIMURA

Kumamoto University Regional Center, The Japan Environment and Children's Study (JECS), 1-1-1 Honjo, Chuou-ku, Kumamoto 8608556, Japan

TEL: +81(96)373-5440, FAX: +81(96)373-5441

E-mail: ri kaimura@yahoo.co.jp
I. 緒言

我が国に拈ける若年女性のや世願望は世界的にみても 非常に高く (1), 20 歳代で低体重 $\left(\mathrm{BMI}<18.5 \mathrm{~kg} / \mathrm{m}^{2}\right)$ に 分類される女性の割合は 1984 年の $12.4 \%$ から 2014 年は $21.5 \% ， 30$ 歳代でも同様に $7.8 \%$ から $17.6 \%$ へと 30 年間 
で約 2 倍に増加している(2)。つまり，妊娠適齢期女性 に低体重が増加していることになる。非妊娠時に低体重 及び低栄養状態にある女性は, 妊娠後も非妊娠時の食 習慣をそのまま引き継き，体重を制限する者が多いこ とが報告されている（3）。非妊娠時の低体重及び妊娠期 間の不十分な体重増加量は, 出生体重が $2,500 \mathrm{~g}$ 未満で ある低出生体重児（Low birth weight infant; LBW）（4）を 発生するリスクが高い $(5) 。 1980$ 年代は $5 \%$ 台であった LBW の割合はそれ以降漸増し，2012 年には $9.6 \%$ と 30 年間で約 2 倍に増加している(6)。LBW では, 胎児期 に低栄養に晒されることにより生活習慣病を発症する 素因が形成され，その後の環境などにより疾病が発症 するといら DOHaD (Developmental Origins of Health and Disease）説が明らかにされている（7）。このため, 非妊 娠時の低体重や妊娠期間の不十分な体重増加量は単に LBW のリスク因子であるだけでなく, 次世代の健康に 深刻な影響を及ぼすことになる。一方，飽食や運動不 足など生活習慣の変化に伴ら過体重人口の増加も報告 されている。非妊娠時の過体重や妊娠期間の過剰な体重 増加量は, 妊娠高血圧症候群 (pregnancy-induced hypertension; PIH) や妊娠糖尿病 (gestational diabetes mellitus; GDM), 帝王切開, 出生体重が $4,000 \mathrm{~g}$ 以上である巨大 児 (Heavy birth weight infant; HBW) (4)，新生児仮死な どの発症リスクが高いことが報告されている $(8-13)$ 。 このように非妊娠時の体格や妊娠期間の体重増加量は, 妊娠・分娩，新生児の合併症などと深く関連している。 したがって, 日本産婦人科学会周産期委員会は妊娠中毒 症予防 (14), 厚生労働省「健やか親子 $21 」$ は産科的異 常の予防及び適正な出生体重 (15), 日本肥満学会「肥 満症診断基準 2011」は産科的異常の減少（16）の観点か ら, 各々非妊娠時の体格区分に応じた妊娠期間の推奨体 重増加量を提唱している。

環境省のプロジェクトである「子どもの健康と環境に 関する全国調査（エコチル調査）」は, 子どもの健康に 影響を及ぼす環境要因の解明を目的とした出生コホート 調査であり, 国立環境研究所を中心に全国 15 か所のユ ニットセンターで行われている。エコチル調査では 2011 年 1 月から 2014 年 3 月の間に約 10 万組の妊婦を リクルートし，胎児期から 13 歳になるまで定期的に健 康状態を追跡している。このリクルート数は各調査地域 の全妊婦及び出生児の約 $50 \%$ 以上のカバー率に值して おり, 調查地域を代表する集団に近いポピュレーション・ ベースの研究となっている。熊本大学は宮崎大学, 琉球 大学とユニットを組む南九州・沖縄ユニットセンターの サブユニットセンター（Sub-Unit Center; SUC）であり, 天草地域，人吉 - 球磨地域，水俣・芦北地域を調査対象 地域として合計 3,082 名の妊婦をリクルートした。熊本 県でも妊娠適齢期女性に打ける低体重の割合の増加がみ られる (17) ことから, 熊本大学 SUCでリクルートした 参加者の特性を明らかにするとともに, 参加者の非妊娠 時体格及び妊娠期間の体重増加量と周産期予後との関連 について検討することを目的とする。

\section{II. 研 究方法}

\section{1. 対象者}

対象は, 熊本大学 SUC の妊娠初期ドクタ一調查票 （Dr-T1）及び分娩時ドクタ一調査票 (Dr-0m)，妊娠中 期質問票（M-T2）の 3 つ全てのデータシステムに参加 登録されている2,996 名のうち，多胎 50 名，死産 6 名, 身長のデータ欠損 1 名を除外した 2,939名を対象とした (2015 年 8 月 28 日時点)。ドクタ一調査票とは, 現在及 び既往の妊娠・分婏に関連する情報を外来診療録から医 療者やリサーチ・コーディネーターが転記したものであ り, M-T2 とは妊娠 23 週以降に健康状態や生活状況に ついて対象者自身が記載する自記式記名式質問票であ る。これらのデータは熊本大学 SUCに扔いて独自にク リーニングを行い, 確定させた。

\section{2. 調査方法}

Dr-T1 及び Dr-0m から非妊娠時情報（身長，体重）, 分娩時情報 (年齢, 分娩直前体重, 分婏歴, 分娩様式, 自然分婏の分娩時間, 在胎週数, 出生体重, 児の性別, 不妊治療の有無), 周産期合併症 (PIH・GDM の有無), M-T2 から生活習慣（喫煙（本人及びパートナー）・飲 酒状況，ここ 1 年間のストレスの有無）を抽出した。

\section{3. 解析方法}

身長と非妊娠時体重，分婏直前体重より，非妊娠時 体格（以下，体格）と妊娠期間の体重増加量（以下，体

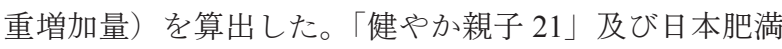
学会の判定基準に従い，体格（Body Mass Index ; BMI : 体重 $(\mathrm{kg}) /$ 身長 $\left.\left(\mathrm{m}^{2}\right)\right)$ が $18.5 \mathrm{~kg} / \mathrm{m}^{2}$ 未満を低体重群, $18.5 \mathrm{~kg} / \mathrm{m}^{2}$ 以上 $25.0 \mathrm{~kg} / \mathrm{m}^{2}$ 未満を標準群, $25.0 \mathrm{~kg} / \mathrm{m}^{2}$ 以 上を過体重群の 3 群に分類した。体格区分別の体重増加 量については，周産期予後との関連を検討するために

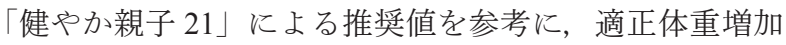
量を低体重群では $9 \mathrm{~kg}$ 以上 $12 \mathrm{~kg}$ 未満，標準群では $7 \mathrm{~kg}$ 以上 $12 \mathrm{~kg}$ 未満と設定し, 適正体重増加量である者を適 正群，それよりも少ない者を過少群，多い者を過剩群に 分類した。過体重群の体重増加量は個別対応とされてい たが，目安として拈执よそ $5 \mathrm{~kg}$ とされていることから 過少群は設けず， $6 \mathrm{~kg}$ 未満を適正群，6 kg 以上を過剩群 に分類した。な报, 本研究では周産期合併症や分婏様式, 分娩時間, 在胎期間, 出生体重などを含めて周産期予後 とする。

コンピューター統計ソフト（IBM SPSS for windows Ver23.0）を用い，有意水準を 5\%未満として以下の検定 を行った。1）体格区分 3 群と特性（年齢, 体重増加量, 不妊治療の有無, 分娩回数, 契煙（本人及びパートナ一）・ 飲酒状況，ストレスの有無），児の性別，周産期予後（在 胎日数 (期間), 出生体重, 分娩時間, 分娩様式, 周産 期合併症），体格区分をさらに体重増加量で分類（以下， 体格区分別体重増加量分類）した 8 群と周産期予後との 関連をみるために $\chi^{2}$ 適合度検定と一元配置分散分析を 行った。その後の比較には, 残差検定, Tukey HSD 検定 を用いた。2）体格区分別体重増加量分類 8 群と 1）に て有意差が見られた周産期予後の項目を従属変数とし 


\begin{tabular}{|c|c|c|c|c|c|c|c|c|c|}
\hline & \multicolumn{2}{|c|}{ 全体 } & \multicolumn{2}{|c|}{ 低体重群 } & \multicolumn{2}{|c|}{ 標淮群 } & \multicolumn{2}{|c|}{ 過体重群 } & \multirow{2}{*}{$\mathrm{P}$ 值 } \\
\hline & 2,939 & (100.0) & 406 & (13.8) & 2,109 & $(71.8)$ & 424 & $(14.4)$ & \\
\hline 年齢※ & 30.4 & $(5.2)$ & 29.5 & $(5.1)$ & 30.6 & $(5.2)$ & 30.6 & $(5.2)$ & $0.001^{\mathrm{a}}$ \\
\hline 体重増加量※ & 10.5 & $(4.0)$ & 11.4 & (3.4) & 10.9 & (3.6) & 8.0 & $(5.1)$ & $<0.001^{\mathrm{a}}$ \\
\hline 不妊治療 & 139 & (4.7) & 20 & (4.9) & 95 & $(4.5)$ & 24 & $(5.7)$ & $0.581^{\mathrm{b}}$ \\
\hline 分婏回数 & & & & & & & & & $0.332^{\mathrm{b}}$ \\
\hline 0 回 & 956 & $(32.6)$ & 136 & (33.5) & 700 & $(33.2)$ & 120 & $(28.4)$ & \\
\hline 1 回 & 999 & $(34.0)$ & 140 & $(34.5)$ & 702 & $(33.3)$ & 157 & $(37.1)$ & \\
\hline 2 回以上 & 981 & $(33.4)$ & 130 & $(32.0)$ & 705 & $(33.5)$ & 146 & $(34.5)$ & \\
\hline 喫煙 & & & & & & & & & $0.025^{\mathrm{b}}$ \\
\hline 経験なし & 1,709 & $(58.6)$ & 241 & $(59.8)$ & 1,238 & $(59.1)$ & 230 & $(55.2)$ & \\
\hline 妊娠前禁煙 & 632 & $(21.7)$ & 74 & (18.4) & 467 & $(22.3)$ & 91 & $(21.8)$ & \\
\hline 妊娠後禁煙 & 439 & $(15.1)$ & 63 & (15.6) & 310 & (14.8) & 66 & $(15.8)$ & \\
\hline あり & 136 & $(4.7)$ & 25 & $(6.2)$ & 81 & $(3.9)$ & 30 & $(7.2)$ & \\
\hline パートナーの契煙 & & & & & & & & & $0.026^{\mathrm{b}}$ \\
\hline 経験なし & 659 & $(22.9)$ & 109 & $(27.4)$ & 460 & $(22.3)$ & 90 & (21.9) & \\
\hline 妊娠前禁煙 & 593 & $(20.6)$ & 67 & $(16.8)$ & 451 & $(21.8)$ & 75 & $(18.2)$ & \\
\hline 妊娠後禁煙 & 83 & $(2.9)$ & 7 & (1.8) & 67 & $(3.2)$ & 9 & $(2.2)$ & \\
\hline あり & 1,541 & $(53.6)$ & 215 & $(54.0)$ & 1,089 & $(52.7)$ & 237 & $(57.7)$ & \\
\hline 飲酒 & & & & & & & & & $0.275^{\mathrm{b}}$ \\
\hline 経験なし & 994 & $(33.9)$ & 149 & $(36.8)$ & 690 & $(32.8)$ & 155 & $(36.8)$ & \\
\hline 妊娠前禁酒 & 502 & $(17.1)$ & 67 & $(16.5)$ & 355 & $(16.9)$ & 80 & $(19.0)$ & \\
\hline 妊娠後禁酒 & 1,336 & $(45.6)$ & 177 & $(43.7)$ & 988 & $(47.0)$ & 171 & $(40.6)$ & \\
\hline あり & 96 & $(3.4)$ & 12 & (3.0) & 69 & $(3.3)$ & 15 & $(3.6)$ & \\
\hline ストレス & 1,238 & $(42.2)$ & 176 & $(43.5)$ & 893 & $(42.4)$ & 169 & $(39.9)$ & $0.531^{\mathrm{b}}$ \\
\hline 男児 & 1,557 & $(53.0)$ & 222 & $(54.7)$ & 1,110 & $(52.6)$ & 225 & $(53.1)$ & $0.750^{\mathrm{b}}$ \\
\hline 在胎日数※ & 273.7 & $(10.2)$ & 273.2 & $(10.2)$ & 273.9 & $(10.1)$ & 272.9 & (11.1) & $0.085^{\mathrm{a}}$ \\
\hline \multicolumn{10}{|l|}{ 出生体重※ } \\
\hline 男児 & 3100.0 & $(427.6)$ & 2977.8 & $(385.2)$ & 3110.7 & $(417.2)$ & 3167.8 & $(492.0)$ & $<0.001^{\mathrm{a}}$ \\
\hline 女児 & 3000.1 & $(410.0)$ & 2910.1 & $(402.3)$ & 2999.0 & $(399.8)$ & 3088.7 & $(449.2)$ & $<0.001^{\mathrm{a}}$ \\
\hline \multicolumn{10}{|l|}{ 分婏時間※ } \\
\hline 初産 & 607.5 & $(349.1)$ & 563.7 & $(309.7)$ & 614.1 & $(353.0)$ & 665.9 & $(428.2)$ & $0.575^{\mathrm{a}}$ \\
\hline 経産 & 328.4 & $(207.2)$ & 313.5 & (181.2) & 330.8 & (211.3) & 338.0 & (221.6) & $0.652^{\mathrm{a}}$ \\
\hline \multicolumn{10}{|l|}{ 分婏様式 } \\
\hline 帝王切開 & 637 & $(21.7)$ & 60 & (14.8) & 421 & $(20.0)$ & 156 & $(36.8)$ & $<0.001^{\mathrm{b}}$ \\
\hline 自然 & 945 & $(32.2)$ & 169 & $(41.6)$ & 695 & $(33.0)$ & 81 & (19.1) & $<0.001^{\mathrm{b}}$ \\
\hline 誘発・促進 & 1,164 & $(39.6)$ & 145 & $(35.7)$ & 857 & $(40.6)$ & 162 & $(38.2)$ & $0.146^{\mathrm{b}}$ \\
\hline 吸引・鉗子 & 193 & $(6.6)$ & 32 & (7.9) & 136 & $(6.4)$ & 25 & (5.9) & $0.472^{\mathrm{b}}$ \\
\hline \multicolumn{10}{|l|}{ 周産期合併症 } \\
\hline 早産 & 147 & $(5.0)$ & 26 & (6.4) & 99 & (4.7) & 22 & $(5.2)$ & $0.345^{\mathrm{b}}$ \\
\hline 過期産 & 3 & $(0.1)$ & 0 & $(0.0)$ & 2 & $(0.1)$ & 1 & $(0.2)$ & $0.557^{\mathrm{b}}$ \\
\hline PIH & 137 & $(4.7)$ & 10 & $(2.5)$ & 89 & $(4.2)$ & 38 & $(9.0)$ & $<0.001^{\mathrm{b}}$ \\
\hline GDM & 29 & (1.0) & 1 & $(0.2)$ & 13 & (0.6) & 15 & (3.5) & $<0.001^{\mathrm{b}}$ \\
\hline LBW & 214 & (7.3) & 44 & (10.9) & 140 & (6.7) & 30 & $(7.2)$ & $0.011^{\mathrm{b}}$ \\
\hline HBW & 32 & (1.1) & 4 & $(1.0)$ & 19 & (0.9) & 9 & (2.1) & $0.085^{\mathrm{b}}$ \\
\hline
\end{tabular}

n (\%), ※; Mean (SD), P 值 : a ; ANOVA, b ; $\chi^{2}$ 検定

分婏時間 : 低体重群 $\mathrm{n}=44 / 125$, 標準群 $\mathrm{n}=177 / 516$, 過体重群 $\mathrm{n}=13 / 68$ （初産 / 経産）

PIH; pregnancy-induced hypertension, GDM; gestational diabetes mellitus, LBW; low birth weight infant, HBW; heavy birth infant

て, 年齢, 分婏回数, 不妊治療, 喫煙（本人及びパート ナー)，飲酒，ストレスで調整した上で，標準体格で適 正体重増加量群を参照値としたロジスティック回帰分析 を行い，各周産期予後のリスクについて検討した。

\section{4. 倫理的配慮}

エコチル調査は環境省及び国立環境研究所に加え, 熊 本大学大学院生命科学研究部等疫学・一般研究倫理委員 会の承認を得て実施している (平成 24 年 9 月 11 日承認, 疫学第 92 号〈変更〉)。また, 対象者には研究目的と方法, 
表 2 体格区分別体重増加量分類による周産期予後

\begin{tabular}{|c|c|c|c|c|c|c|c|c|c|c|c|c|c|c|c|c|c|}
\hline & \multicolumn{6}{|c|}{ 低体重 } & \multicolumn{6}{|c|}{ 標準 } & \multicolumn{4}{|c|}{ 過体重 } & \multirow{3}{*}{ P 值 } \\
\hline & \multirow{2}{*}{\multicolumn{2}{|c|}{$\begin{array}{c}\text { 過少群 } \\
97 \text { (23.9) }\end{array}$}} & \multicolumn{2}{|c|}{ 適正群 } & \multicolumn{2}{|c|}{ 過利群 } & \multicolumn{2}{|c|}{ 過少群 } & \multicolumn{2}{|c|}{ 適正群 } & \multicolumn{2}{|c|}{ 過唾群 } & \multicolumn{2}{|c|}{ 適正群 } & \multicolumn{2}{|c|}{ 過剰群 } & \\
\hline & & & 182 & (44.8) & & (31.3) & 260 & (12.3) & 1,268 & $(60.2)$ & 579 & $(27.5)$ & 128 & $(30.2)$ & 296 & $(69.8)$ & \\
\hline 在胎日数※ & 269.5 & $5(13.3)$ & 274.1 & $(9.7)$ & 274.7 & $(7.0)$ & 269 & (16.4) & 273.7 & $(8.8)$ & 276.4 & (8.0) & 271.1 & (11.5) & 273.7 & $(10.9)$ & $<0.001^{\mathrm{a}}$ \\
\hline 出生体重※ & 2754.8 & (467.2) & 2945.1 & $(355.2)$ & 3096.8 & $(316.9)$ & 2852.2 & (519.8) & 3042.0 & $(386.6)$ & 3185.1 & (369.6) & 3029.9 & (473.6) & 3174.3 & $(467.6)$ & $<0.001^{\mathrm{a}}$ \\
\hline \multicolumn{18}{|l|}{ 分婏時間 $※$} \\
\hline 初産 & 653.3 & $3(327.1)$ & 555.0 & $(334.0)$ & 456.1 & (164.6) & 589.3 & (441.7) & 649.0 & $(342.2)$ & 547.7 & (313.8) & 667.0 & $(186.7)$ & 665.6 & (465.3) & $0.605^{\mathrm{a}}$ \\
\hline 経産 & 281.6 & $5(126.3)$ & 336.5 & (197.8) & 311.2 & (195.1) & 353.6 & $(214.2)$ & 330.9 & $(211.2)$ & 312.0 & $(165.5)$ & 354.1 & (196.0) & 331.3 & $(233.1)$ & $0.777^{\mathrm{a}}$ \\
\hline \multicolumn{18}{|l|}{ 分婏様式 } \\
\hline 帝王切開 & 18 & (18.6) & 24 & (13.2) & 18 & (14.2) & 52 & $(20.0)$ & 257 & (20.3) & 112 & (19.3) & 50 & (39.1) & 106 & $(35.8)$ & $<0.001^{\mathrm{b}}$ \\
\hline 自然 & & $(45.4)$ & 73 & $(40.1)$ & 52 & (40.9) & 101 & (38.8) & 456 & $(36.0)$ & 137 & (23.7) & 22 & (17.2) & 59 & (19.9) & $<0.001^{\mathrm{b}}$ \\
\hline 誘発・促進 & & $(35.1)$ & 67 & (36.8) & 44 & (34.6) & 87 & $(33.5)$ & 479 & (37.8) & 291 & $(50.3)$ & 46 & (35.9) & 116 & $(39.2)$ & $<0.001^{\mathrm{b}}$ \\
\hline 吸引・鉗子 & 1 & $(1.0)$ & 18 & $(9.9)$ & 13 & (10.2) & 20 & $(7.7)$ & 76 & $(6.0)$ & 39 & (6.7) & 10 & (7.8) & 15 & (5.1) & $0.059^{\mathrm{b}}$ \\
\hline \multicolumn{18}{|l|}{ 周産期合併症 } \\
\hline 早産 & & (15.5) & 10 & $(5.5)$ & & $(0.8)$ & 31 & (11.9) & 54 & (4.3) & 14 & (2.4) & 10 & (7.8) & 12 & (4.1) & $<0.001^{\mathrm{b}}$ \\
\hline 過期産 & 0 & $(0.0)$ & 0 & $(0.0)$ & & $(0.0)$ & 0 & $(0.0)$ & 1 & $(0.1)$ & 1 & $(0.2)$ & 1 & $(0.8)$ & 0 & $(0.0)$ & $0.417^{\mathrm{b}}$ \\
\hline $\mathrm{PIH}$ & 3 & $(3.1)$ & 2 & (1.1) & & (3.9) & 15 & $(5.8)$ & 41 & (3.2) & 33 & $(5.7)$ & 14 & (10.9) & 24 & (8.1) & $<0.001^{\mathrm{b}}$ \\
\hline GDM & 0 & $(0.0)$ & 0 & $(0.0)$ & & $(0.8)$ & 6 & $(2.3)$ & 6 & $(0.5)$ & 1 & $(0.2)$ & 8 & $(6.3)$ & 7 & (2.4) & $<0.001^{\mathrm{b}}$ \\
\hline LBW & & (22.9) & 18 & (9.9) & & (3.2) & 38 & (14.7) & 87 & (6.9) & 15 & (2.6) & 12 & $(9.4)$ & 18 & $(6.2)$ & $<0.001^{\mathrm{b}}$ \\
\hline HBW & 1 & (1.0) & 1 & $(0.5)$ & 2 & (1.6) & 2 & $(0.8)$ & 10 & $(0.8)$ & 7 & $(1.2)$ & 1 & $(0.8)$ & 8 & (2.7) & $0.224^{\mathrm{b}}$ \\
\hline
\end{tabular}

$\mathrm{n}(\%), ※ ;$ Mean $(\mathrm{SD}), \mathrm{P}$ 值: $\mathrm{a} ;$ ANOVA, $\mathrm{b} ; \chi^{2}$ 検定，分婏時間; 低体重: 過少群 $\mathrm{n}=12 / 32$, 適正群 $\mathrm{n}=24 / 49$, 過㮃群 $\mathrm{n}=8 / 44$, 標準 : 過少群 $\mathrm{n}=27 / 73$, 適正群 $\mathrm{n}=105 / 35$, 過剩群 $\mathrm{n}=45 / 20$, 過体重 : 適正群 $\mathrm{n}=2 / 20$, 過剩群 $\mathrm{n}=11 / 48$ （初産 / 経産）

PIH; pregnancy-induced hypertension, GDM; gestational diabetes mellitus, LBW; low birth weight infant, HBW; heavy birth weight infant

研究協力の任意性と撤回の自由，参加することによる利 益と不利益，個人情報保護のための対策，データの取り 扱いと廃棄, 研究成果の発表方法などについて文書及び 口頭にて説明し，同意書を得た上で調査を実施している。

\section{III. 結果}

\section{1）対象者の特性}

全体及び体格区分別の対象者の特性，周産期予後を 表 1 に示す。対象者の平均年齢は $30.4 \pm 5.2$ 歳であり, $32.6 \%$ が初産婦であった。本人及びパートナーの妊娠中 の契煙の割合は各 $4.7 \%, 53.6 \%$ であり，妊娠中の飲酒 は $3.4 \%$ ，ストレスを有する者は $42.2 \%$ であった。出生 児の $53.0 \%$ が男児であり，平均在胎日数は $273.7 \pm 10.2$ 日，早産，過期産の割合は各 $5.0 \%, 0.1 \%$ であった。平 均出生体重は男児 $3100.0 \pm 427.6 \mathrm{~g}$, 女児 $3000.1 \pm 410.0 \mathrm{~g}$ で, LBW, HBW の割合は各 $7.3 \%, 1.1 \%$ であった。分 娩様式は誘発・促進分娩が $39.6 \%$ と最も多く, 次いで 自然分娩が $32.2 \%$ ，帝王切開が $21.7 \%$ であった。

対象者の特性を体格区分別にみると, 低体重群 $13.8 \%$ ，標準群 $71.8 \%$ ，過体重群 $14.4 \%$ であり，体格が 大きい注ど体重増加量は小さかった。低体重群は他の 2 群に比べ平均年齢が低く, 過体重群は本人特よびパート ナーの契煙の割合が高かった。

\section{2）体格区分及び体格区分別体重増加量分類による周産 期予後}

体格区分 3 群と周産期予後との関連を検討した。在胎 日数は 3 群間で有意な差は認められなかった。自然分婏 による分娩時間は初産・経産ともに体格が大きい汪ど長 かったが, 3 群間で有意な差は認められなかった。分娩様
式では, 過体重群は他の 2 群に比べ帝王切開の割合が高 く, 低体重群は自然分娩の割合が高かった。周産期合併症 では, 過体重群は他の 2 群に比べPIH と GDMの割合が高 かった。また, 平均出生体重は体格が大きいほど大きく, 低体重群は他の 2 群に比べLBW の割合が高かったが, HBW の割合は 3 群間で有意な差は認められなかった。

さらに, 体格区分別体重増加量分類 8 群之周産期予後 との関連を検討した（表 2)。分娩時間と吸引・鉗子分娩, 過期産, HBW を除き, 在胎日数, 出生体重, 分婏様式, 周産期合併症において 8 群間で有意な差を認めた。8 群 の中で，自然分婏の割合は体重増加量に関わらず低体重 群, 及び標準体格の過少群と適正群に高く, 誘発・促進 分娩は標準体格の過利群に高かった。また，帝王切開と PIH, GDM の割合は体重増加量に関わらず過体重群に 高く, 早産と LBW の割合は体格区分に関わらず過少群 に高かった。

表 2 で有意差が認められた周産期予後の項目を対象 に，年齢や分娩回数，不妊治療，喫煙（本人及びパート ナー), 飲酒, ストレスなどの生活背景を調整した上で, 標準体格で適正体重増加量群を参照值とした体格区分別 体重増加量分類による周産期予後のリスクについて検討 した（表 3)。まず，分婏様式では，自然分婏のオッズ比 は標準体格の過剰群 (OR; $0.5895 \% \mathrm{Cl} ; 0.46-0.73)$ と体重 増加量に関わらず過体重群（適正群 : OR; 0.36 95\%Cl; 0.22-0.59, 過剩群 : OR; $0.4595 \% \mathrm{Cl} ; 0.32-0.61)$ で減少 した。一方，帝王切開のオッズ比は体重増加量に関わら ず過体重群（適正群: OR; $2.6595 \% \mathrm{Cl} ; 1.79-3.93$, 過剰群: OR; $2.1795 \% \mathrm{Cl} ; 1.64-2.89)$ で増大し, 誘発・促進分婏 のオッズ比は標準体格の過剰群（OR; $1.6595 \% \mathrm{Cl} ; 1.35-$ 2.02）にて増大した。次に，周産期合併症では早産の オッズ比は体格に関わらず過少群（低体重群 : OR; 4.02 
表 3 体格区分別体重増加量分類による周産期予後のリスク

\begin{tabular}{|c|c|c|c|c|c|c|c|c|c|c|c|c|}
\hline & \multicolumn{4}{|c|}{ 低体重 } & \multicolumn{3}{|c|}{ 標準 } & \multicolumn{2}{|c|}{ 過体重 } & \multirow[b]{2}{*}{ 年齢 } & \multirow[b]{2}{*}{ 分婏回数 } & \multirow[b]{2}{*}{ 喫煙 } \\
\hline & & $\begin{array}{c}\text { 過少群 } \\
97(23.9)\end{array}$ & $\begin{array}{c}\text { 適正群 } \\
182(44.8)\end{array}$ & $\begin{array}{c}\text { 過剩群 } \\
127(31.3)\end{array}$ & $\begin{array}{c}\text { 過少群 } \\
260(12.3)\end{array}$ & $\begin{array}{c}\text { 適正群 } \\
1,268(60.2)\end{array}$ & $\begin{array}{c}\text { 過剩群 } \\
579(27.5)\end{array}$ & $\begin{array}{c}\text { 適正群 } \\
128(30.2)\end{array}$ & $\begin{array}{c}\text { 過剩群 } \\
296 \text { (69.8) }\end{array}$ & & & \\
\hline \multicolumn{13}{|l|}{ 分婏様式 } \\
\hline \multirow[t]{3}{*}{ 帝王切開 } & OR & 0.88 & 0.60 & 0.57 & 0.99 & 1 & 0.91 & 2.65 & 2.17 & 1.05 & 0.71 & \\
\hline & $95 \% \mathrm{Cl}$ & $0.51-1.52$ & $0.38-0.94$ & $0.33-1.01$ & $0.70-1.39$ & referent & $0.70-1.17$ & $1.79-3.93$ & $1.64-2.89$ & $1.03-1.07$ & $0.63-0.80$ & \\
\hline & $\mathrm{P}$ 值 & 0.641 & 0.025 & 0.055 & 0.941 & & 0.460 & $<0.001$ & $<0.001$ & $<0.001$ & $<0.001$ & \\
\hline \multirow{3}{*}{ 自然 } & OR & 1.55 & 1.22 & 1.24 & 1.20 & 1 & 0.58 & 0.36 & 0.45 & 0.97 & 1.37 & \\
\hline & $95 \% \mathrm{Cl}$ & $1.01-2.36$ & $0.88-1.68$ & $0.84-1.82$ & $0.91-1.59$ & referent & $0.46-0.73$ & $0.22-0.59$ & $0.32-0.61$ & $0.96-0.99$ & $1.23-1.52$ & \\
\hline & $\mathrm{P}$ 值 & 0.044 & 0.230 & 0.279 & 0.202 & & $<0.001$ & $<0.001$ & $<0.001$ & 0.001 & $<0.001$ & \\
\hline \multirow[t]{3}{*}{ 誘発 • 促進 } & OR & 0.87 & 0.96 & 0.87 & 0.80 & 1 & 1.65 & 0.86 & 1.10 & & & \\
\hline & $95 \% \mathrm{Cl}$ & $0.56-1.34$ & $0.69-1.32$ & $0.59-1.28$ & $0.60-1.06$ & referent & $1.35-2.02$ & $0.58-1.27$ & $0.84-1.43$ & & & \\
\hline & $\mathrm{P}$ 值 & 0.526 & 0.796 & 0.474 & 0.120 & & $<0.001$ & 0.436 & 0.494 & & & \\
\hline \multicolumn{13}{|l|}{ 周産期合併症 } \\
\hline \multirow[t]{3}{*}{ 早産 } & OR & 4.02 & 1.36 & 0.19 & 3.18 & 1 & 0.56 & 1.64 & 1.04 & & & \\
\hline & $95 \% \mathrm{Cl}$ & $2.14-7.58$ & $0.68-2.73$ & $0.03-1.42$ & $1.98-5.10$ & referent & $0.30-1.03$ & $0.76-3.53$ & $0.55-1.98$ & & & \\
\hline & $\mathrm{P}$ 值 & $<0.001$ & 0.384 & 0.106 & $<0.001$ & & 0.062 & 0.211 & 0.907 & & & \\
\hline \multirow[t]{3}{*}{$\mathrm{PIH}$} & OR & 0.61 & 0.34 & 1.54 & 1.74 & 1 & 1.92 & 3.52 & 2.54 & 1.08 & 0.91 & \\
\hline & $95 \% \mathrm{Cl}$ & $0.15-2.59$ & $0.08-1.41$ & $0.59-4.01$ & $0.95-3.21$ & referent & $1.19-3.08$ & $1.82-6.82$ & $1.49-4.36$ & $1.04-1.11$ & $0.56-0.88$ & \\
\hline & $\mathrm{P}$ 值 & 0.506 & 0.136 & 0.376 & 0.070 & & 0.007 & $<0.001$ & $<0.001$ & $<0.001$ & 0.002 & \\
\hline \multirow[t]{3}{*}{ GDM } & OR & 0.00 & 0.00 & 2.84 & 5.43 & 1 & 0.48 & 17.35 & 4.61 & 1.13 & & \\
\hline & $95 \% \mathrm{Cl}$ & 0.00 & 0.00 & $0.32-24.82$ & $1.63-18.03$ & referent & $0.06-4.10$ & $5.52-54.53$ & $1.32-16.10$ & $1.04-1.21$ & & \\
\hline & $\mathrm{P}$ 值 & 0.997 & 0.996 & 0.346 & 0.006 & & 0.499 & $<0.001$ & 0.017 & 0.002 & & \\
\hline \multirow[t]{3}{*}{ LBW } & OR & 4.04 & 1.45 & 0.44 & 2.27 & 1 & 0.32 & 1.27 & 0.86 & 1.03 & 0.74 & 1.35 \\
\hline & $95 \% \mathrm{Cl}$ & $2.35-6.93$ & $0.84-2.48$ & $0.16-1.22$ & $1.49-3.46$ & referent & $0.18-0.58$ & $0.65-2.46$ & $0.51-1.47$ & $1.00-1.06$ & $0.61-0.89$ & $0.06-0.58$ \\
\hline & $\mathrm{P}$ 值 & $<0.001$ & 0.178 & 0.115 & $<0.001$ & & $<0.001$ & 0.483 & 0.586 & 0.04 & 0.002 & $<0.001$ \\
\hline
\end{tabular}

n (\%), P 值 ; ロジスティック回帰分析，調整因子 ; 年齢，分婏回数，不妊治療，喫煙，飲酒，ストレス， OR; Odds Ratio, CL; Confidence Interval, PIH; pregnancy-induced hypertension, GDM; gestational diabetes mellitus, LBW; low birth weight infant, HBW; heavy birth weight infant

95\%Cl; 2.14-7.58，標準群 : OR; $3.1895 \% \mathrm{Cl} ; 1.98-5.10)$ にて増大し，LBW も同様であった（低体重群 : OR; 4.04 95\%Cl; 2.35-6.93，標準群 : OR; 2.27 95\%Cl; 1.49-3.46)。 一方, PIH のオッズ比は体重増加量に関わらず過体重群 (適正群 : OR; $3.5295 \% \mathrm{Cl} ; 1.82-6.82$, 過剰群 : OR; 2.54 95\%Cl; 1.49-4.36）にて増大し, GDM も同様であった（適 正群 : OR; 17.35 95\%Cl; 5.52-54.53，過剩群 : OR; 4.61 95\%Cl; 1.32-16.10)。加えて, PIH は標準体格の過剩群 （OR；1.92 95\%Cl；1.19-3.08）で，GDM は標準体格の過 少群（OR; $5.4395 \% \mathrm{Cl} ; 1.63-18.03 ）$ に打いても増大した。 なお，調整因子の中でも本人の喫煙により，LBWのリ スクは増大した（OR; $1.3595 \% \mathrm{Cl} ; 0.06-0.58 ） 。$

\section{IV. 考 察}

本研究は, 全国 15 か所で行っているエコチル調査の らち, 熊本大学 SUC の参加者の特性を明らかにすると ともに, 非妊娠時体格及び妊娠期間の体重増加量と周産 期予後との関連について検討することを目的に行った。 本研究の結果について，1）本対象者の特性，2）体格区 分及び体格区分別体重増加量分類と周産期予後との関連 について考察する。

\section{1）本対象者の特性}

本対象者の特性について検討するために，人口動態調 査などの全国調査と比較した（表 4）。本対象者の年齢
を5歳階級別にみると，30-34 歳と 25-29 歳が同率で最 も多く，次いで35-39歳であり，全国調査（18）では 30-34 歳, 25-29 歳, 35-39 歳の順に多かった。本対象 者の体格は低体重 $13.8 \%$ ，標準 $71.8 \%$ ，過体重 $14.4 \%$ で あり，全国調査（20-40 歳代女性）（19）は各 16.7\%, $72.8 \% ， 12.9 \%$ であった。生活習慣をみると，妊娠中の 喫煙率は全国調査（20）と大差なかったが，飲酒率は低 い傾向が同えた。ストレスを有する割合は本対象者の方 が低かったが，本研究ではストレスの有無のみを質問し ているのに対し，全国調査（21）では悩みとストレスの 有無について質問しており，この質問の違いが一因であ ると推測する。平均出生体重と男児, 帝王切開, 早産, 過期産， LBW，HBW の割合などは，全国調査 $(18,22)$ と同程度であった。これらのことより，本対象者は熊本 県でも郡部に位置する調査地域の集団であることから偏 りはあるが，我が国の一般集団と類似の傾向であり，あ る程度一般妊婦の参考に供しらると考えられる。な报, 本対象者の分婏様式をみると, 誘発・促進分婏が最も多 かった。従来, 妊娠 37 週から 41 週の医学的適応がない 誘発分婏の利益は限定的であり，熊本県でも都市部の総 合医療機関では医学的適応がない誘発分娩は行わない傾 向にある。しかし，本対象は郡部の開業医療機関が主で あり，母体・胎児側適応に加光妊婦の交通事情や医療側 の管理体制などの社会的適応などから，予防的に計画分 婏が選択された者が多かったのではないかと推測する。 
表 4 対象者と全国データとの比較

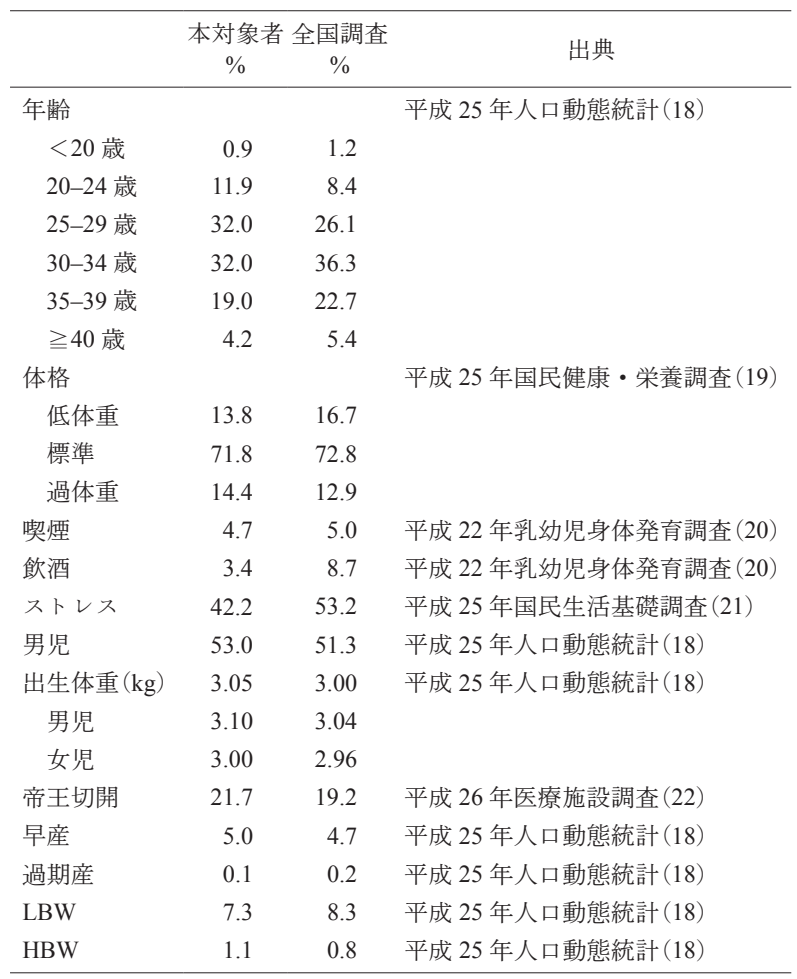

LBW; low birth weight infant, HBW; heavy birth weight infant

\section{2）体格区分及び体格区分別体重増加量分類と周産期予 後との関連}

分婏様式では，自然分婏の割合は体格区分 3 群の中で 低体重群に高く,帝王切開の割合は過体重群に高かった。 体格区分別体重増加量分類によるリスクをみると，自然 分婏のオッズ比は体重増加量に関わらず過体重群と標準 体格の過剩群で減少した。一方, 帝王切開のリスクは体 重増加量に関的らず過体重群にて, 誘発・促進分婏のリ スクは標準体格の過剩群にて増大した。過体重体格や過 剩な体重増加量により, 自然分婏から帝王切開や誘発・ 促進などの医療介入分娩が増加することは周知である。 Mamun ら (23) は, 過体重体格で過剩な体重増加量の場 合に帝王切開のリスクが増大寸ると報告している。一方, Young ら（24）は過体重体格では体重増加量と関連なく 帝王切開率が高い, Abramsら (25) は標準体格では体重 増加量と帝王切開の関連は明らかでないと報告してい る。本研究は Young ら (24) や Abrams (25) らを支持す る結果であり, 帝王切開のリスク要因は過体重体格であ ることが示唆される。しかし, 本研究では既存のデータ 飞帝王切開が予定か緊急かの記載がないため, 検討でき なかった。過剩な体重増加量は緊急帝王切開に影響を及 ぼしている可能性があり，今後はこれらの症例を分けて 検証する必要がある。

周産期合併症では，まず，LBW の割合は低体重群に 高く, 体格区分別体重増加量分類によるリスクでは，早 産と LBW のリスクは体格に関わらず過少群において増 大した。妊娠中の体重増加量と胎児発育との関連につい て, 管ら (26) は, 体重増加量が不十分な場合, 胎児が 低栄養状態に晒されることにより母体から胎児へのアミ
ノ酸輸送機能が低下し，子宮内胎児発育不全の発症りス クが高まるとともに，出生体重にも影響すると考光，妊 娠中の体重増加量によって胎盤重量や合胞体栄養膜細胞 容積，アミノ酸輸送蛋白の発現といった胎盤機能が修飾 され，児の出生体重が変化すると示唆している。このこ とから, LBWのリスクには低体重よりも過少な体重増 加量の影響が大きいと考兄られる。我が国に打故る出生 体重は 1973 年をピークに 2005 年まで減少し, その後横 ばいが続いている。また，LBW と胎内発育不全である Light for Gestational Age Infant の割合はともに増加して いる (6)。これらの状況は, $\mathrm{DOHaD}$ 説の観点から将来 の生活習慣病を茩起する危険性の増大を示寸危惧すべき 問題である。吉田ら（27）は，細い体型が好まれる社会 的風潮に加兄, 妊娠中の厳しい体重管理から栄養摂取が 控觉られるようになり, 妊娠期間の体重増加量が減少傾 向になったと指摘している。このため，妊娠期間の過剩 なカロリ一摂取制限の弊害とともに，適切な体重増加量 について社会的に喚起する必要がある。また, 喫煙も LBW のリスクを増大させる要因であった。20歳〜 39 歳女性の契煙率はこの 25 年間で大差ないものの $12.4 \%$ （19）であり，喫煙による胎児への影響について子周知 する必要がある。早産の場合は娃娠期間が短いため，体 重増加量が少ないものと推察する。次に, PIH と GDM の割合は過体重群に高く, 体格区分別体重増加量分類に よるリスクでは，これらは体重増加量に関わらず過体重 群において増大した。加えて, PIH のリスクは標準体格 の過剩群に抢いても増大したことから, 前出の過体重群 や過剩群に和いて帝王切開や誘発・促進分婏のリスクを 増大させた要因の一つに, PIH や GDM が影響している ものと考光られる。さらに, 過少な体重増加量にて GDMのリスクが増大した。Murakamiら（28）は過体重 体格では PIH と GDM の発症率は高いが, 体重増加量は これらの発症と関連はないと報告している。本研究の過 体重体格と PIH 及び GDM との関連は Murakami ら (28) と同様の結果であり, これらの発症には非娃娠時の過剩 な栄養状態が綿密に関与していることが示唆される。し かし，体重増加量との関連は異なり，標準体格では体重 増加量が増大寸るにつれて $\mathrm{PIH}$ の発症率が上昇したと 報告するDeVaderら（29）を支持する結果であった。一方， 過体重体格飞関わらず，GDM と䛦断さ机極端にエネル ギー量を制限する症例が報告されて和り（30）、これが 標準体格の過少群とGDM との関連に影響していること も推測されるが, 今後の検討課題である。本研究では基 礎疾患合併症を除外せずに検討したが，特に糖尿病や本 態性高血圧なぞの合併妊娠は過体重群に多く含まれてい ると考光られる。これらは周産期予後に影響を及活して いる可能性が高く, 今後は基礎疾患合併妊娠症を除外し た上で結果を検証する必要がある。さらに，周産期予後 には体格及び体重増加量以外飞も様々な要因が複雑に影 響しあっていることなどから，結果の解釈は慎重飞行う べきである。なお，妊娠前の身長・体重は自己申告であ るために信頼性に疑問はあるが，結果への影響は大きく ないと考光る。

非妊娠時体格や妊娠期間の体重増加量は周産期予後の みならず，次世代の生活習慣病といら長期的な予後とも 
関連することから，妊娠前からの適切な体格及び妊娠期 は推奨体重増加量を維持することが重要である。このた めには，高校生等を含め妊娠前の女性に対して健康的な 体格や栄養状態を適切に管理するための保健指導を行ら など，早期からの対策が必要である。

\section{謝辞}

本研究の遂行に当たり，貴重なご助言をくださいまし たエコチル調査熊本大学サブユニットセンターの諸先生 方に心から感謝を申し上げます。本研究は環境省の子ぞ もの健康と環境に関する全国調査に係る予算の一部を使 用しました。本論文に示した見解は著者自らのものであ り，必ずしも環境省の見解を示すものではありません。

利益相反はない。

\section{文献}

(1) Sugawara A, Saito K, Sato M, et al. Thinness in Japanese. Epidemiology 2009;20(3):464-465.

（2）厚生労働省. 平成 25 年国民健康 - 栄養調査報告, 2013. http://www.mhlw.go.jp/bunya/kenkou/eiyou/dl/h25houkoku.pdf (2016.1.3)

（3）渡邊浩子．エビデンスにもとづいた妊婦の体重管理. 助産雑誌 2007;61(10):834-839.

(4) ICD-10. 国際疾病分類による新生児の分類. ウェル ネスからみた母性看護過程十病態関連図. 東京 : 医学 書院, 2013, 822 .

( 5 ) Ehrenberg HM, Dierker L, Milluzzi C, et al. Low meternal weight, failure to thrive in pregnancy, and adverse pregnancy outcomes. Am J Obstet Gynecol 2003;189(6):1726-1730.

(6) 財団法人母子衛生研究会（編）。母子保健の主なる統 計。東京：母子保健事業団, 2008.

( 7 ) Gillman MW. Development origins of health and desease. N Engl J Med 2005;353:1848-1850.

( 8 ) Hanson M, Godfrey KM, Lillycrop KA, et al. Developmental plasticity and developmental origins of noncommunicable disease: theoretical considerations and epigenetic mechanisms. Prog Biophys Mol Biol 2011;106: 272-280.

( 9 ) Morikawa M, Yamada T, Yamada T, et al. Prevalence of hyperglycemia during pregnancy according to maternal age and pre-pregnancy body mass index in Japan, 2007-2009. Int J Gynaecol Obstet 2012;118(3):198-201.

(10) Hedderson MM, Gunderson EP, Ferrara A. Gestational weight gain and risk of gestational diabetes mellitus. Obstet Gynecol 2010;115(3):597-604.

(11) Rode L, Hegaard HK, Kjærgaad H, et al. Association between maternal weight gain and birth weight. Obstet Gynecol 2007;109(6):1309-1315.

(12) Stotland NE, Cheng YW, Hopkings LM, et al. Gestational weight gain and adverse neonatal outcome among term infants. Obstet Gynecol 2006;108(3):635-643.

(13) Hedderson MM, Weiss NS, Sacks DA, et al. Pregnancy weight gain and risk neonatal complications: macrosomia, hypoglycemia, and hyperbilirubinemia. Obstet Gynecol 2006;108(5):1153-1161.

（14）中林正雄．妊娠中毒症の栄養管理指針．日本産婦人科 雑誌 1999;51(12):507-510.

（15）厚生労働省．妊産婦のための食生活指針一「健やか親 子 $21 」$ 推進検討会報告書. http://rhino.med.yamanashi. ac.jp/sukoyaka/ninpu_syoku.html (2016.1.3)

（16）日本肥満学会. 肥満研究:肥満症診断基準 2011. 大阪; 日本肥満学会, 2011.

（17）熊本県. 平成 23 年度熊本県県民健康・栄養調査報告書, 2011. http://www.pref.kumamoto.jp/common/UploadFile Output.ashx?c_id $=3 \&$ id $=2573 \&$ sub_id $=1 \&$ flid $=6 \&$ dan $\mathrm{id}=1(2016.1 .3)$

（18）厚生労働省. 平成 25 年人口動態統計，2013．http:// www.mhlw.go.jp/toukei/saikin/hw/jinkou/kakutei13/index. html (2016.11.1)

（19）厚生労働省．平成 25 年国民健康 - 栄養調査， 2013. http://www.mhlw.go.jp/bunya/kenkou/eiyou/h25-houkoku. html (2016.11.1)

（20）厚生労働省. 平成 22 年乳幼児身体発育調查報告書, 2011. http://www.mhlw.go.jp/file/04-Houdouhappyou11901000-Koyoukintoujidoukateikyoku-Soumuka/zenntai. pdf (2016.2.24)

（21）厚生労働省. 平成 25 年国民生活基礎調査の概況, 2013. http://www.mhlw.go.jp/toukei/saikin/hw/k-tyosa/ k-tyosa13/index.html (2016.11.1)

（22）厚生労働省．平成 26 年医療施設（静態・動態）調査 - 病院報告の概況，2014. http://www.mhlw.go.jp/toukei/ saikin/hw/iryosd/14/dl/gaikyo.pdf (2016.11.1)

(23) Mamun AA, Callaway LK, O’Callaghan MJ, et al. Associations of maternal pre-pregnancy obesity and excess pregnancy weight gains with adverse pregnancy outcomes and length of hospital stay. BMC Pregnancy Childbirth 2011;11:62.

(24) Young TK, Woodmansee B. Factors that are associated with cesarean delivery in a large private practice: the importance of prepregnancy body mass index and weight gain. Am J Obstet Gynecol 2002;187(2):318-320.

(25) Abrams B, Altman SL, Pickett KE. Pregnancy weight gain: still controversial. Am J Clin Nutr 2000;71(5 Suppl): 1233S-1241S.

（26）管 礼子，愛甲悠希代，Askew DJ，他. 妊娠中の体 重変化が胎盤アミノ酸輸送機能に与兄る影響. 産婦人 科治療 2011;103(5):550-556.

（27）吉田穂波，加藤則子，横山徹爾. 人口動態統計からみ た長期的な出生体重の変化と要因について．保健医療 科学 2014;63(1):2-16.

(28) Murakami M, Ohmichi M, Takahashi T, et al. Pregnancy body mass index as an important predictor of pregnancy outcomes in Japanese. Arch Gynecol Obstet 2005; 271(4):311-315.

(29) DeVader SR, Neeley HL, Myles TD, et al. Evaluation of gestational weight gain guidelines for women with normal prepregnancy body mass index. Obstet Gynecol 2007; 110(4):745-751.

（30）中尾矢央子，松山香子，前田千穂，他． 新診断基準に よる妊娠糖尿病の管理の重要性. 糖尿病と妊娠 2013; 13(1):132-136 